p-ISSN. 2086-9029

e-ISSN. 2654-5675

Vol. 21 No. 1, HIm. 1-124, Juni 2019

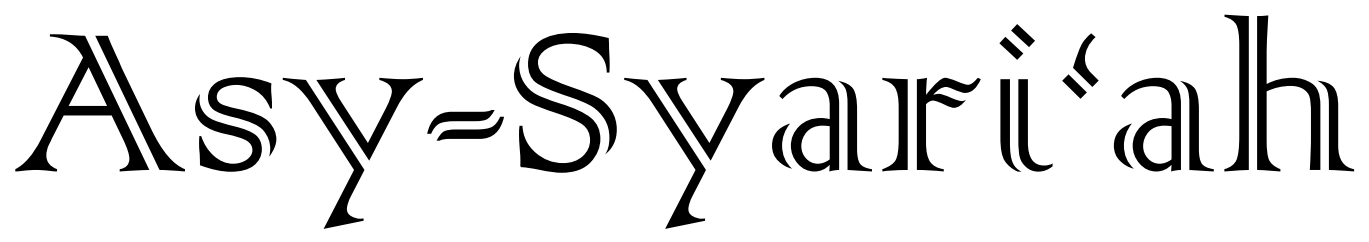

- Islam Nusantara's Perspective on Justice in Polygamy

Beni Ahmad Saebani

- Konstruksi Wakaf Secara Fikih

$(17-30)$ Jaenudin

- Pendekatan Maqashid Syari'ah dalam Praktik Pembiayaan di Koperasi Peternak Sapi Bandung Utara (KPSBU) Lembang Ade Iskandar Nasution

- Kaidah-Kaidah Islam Menjawab Permasalahan Sosial dan Ekonomi Umat

Neneng Hasanah dan Hamzah

- Inovasi Penyaluran Dana Zakat Pada Program Pemberdayaan di Lembaga Amil Zakat

Iw an Setiawan

- Perspektif Siyasah Dusturiyah atas Hak Politik Perempuan dalam Musrembang Kota Bogor

Erma Yulianis

- $\quad$ SBSN PBS, dan SUKRI sebagai Instrumen Pemerintah dalam

Pembiayaan APBN dan Investasi Masyarakat

Suteja Wira Dana Kusuma \& Nisa Dely Amalia

- Partisipasi Politik Kaum Perempuan berdasarkan Pandangan

Fatima Mernissi dan Yusuf Qardhawi

Gayatri Belina Jourdy

FACULTY OF SHARIA AND LAW

STATE ISLAMIC UNIVERSITY SUNAN GUNUNG DJATI BANDUNG-INDONESIA IN COLLABORATION WITH ASOSIASI SARJANA SYARIAH INDONESIA 


\section{Asy-Syari'ah}

\section{Volume 21, Number 1, 2019}

\section{EDITOR-IN-CHIEF}

Ine Fauzia

\section{EDITORIAL BOARD}

Sofyan al-Hakim, UIN Sunan Gunung Djati Bandung, Indonesia Deni Kamaludin Yusup, UIN Sunan Gunung Djati Bandung, Indonesia Meria Utama, Fakultas Hukum Univrsitas Sriwijaya, Indonesia Dewi Mayaningsih, UIN Sunan Gunung Djati Bandung, Indonesia Andrey Sujatmiko, Fakultas Hukum Universitas Trisakti, Jakarta, Indonesia Hetty Hassanah, Universitas Komputer Indonesia, Indonesia

\section{PEER-REVIEWERS}

Muhammad Irfan Helmy, IAIN Salatiga, Semarang, Indonesia Ahmad Ali Nurdin, UIN Sunan Gunung Djati Bandung Tajul Arifin, UIN Sunan Gunun Djati Bandung, Indonesia Mohamad Anton Athoillah, UIN Sunan Gunung Djati Bandung, Indonesia Mrs. Renny Supriyatni, Universitas Padjadjaran, Indonesia Ahmad Tholabi Karlie, UIN Syarif Hidayatullah Jakarta, Indonesia Ija Suntana, UIN Sunan Gunung Djati Bandung, Indonesia Zezen Zaenal Mutaqin, University of California, Los Angeles, United States Ahmad Fathonih, UIN Sunan Gunung Djati Bandung, Indonesia Rahman Syamsuddin, Universitas Islam Negeri Alauddin Makassar, Indonesia

\section{PROOFREADER/DESIGN COVER}

Nanang Sungkawa

\section{LAYOUT EDITOR}

Opik Rozikin

Asy-Syari' ah has been accredited based on the determination of Director General of Research and Development Strengthening, Ministry of Research, Technology and Higher Education of Republic of Indonesia, No. 14/E/KPT/2019 (valid until 2023). 


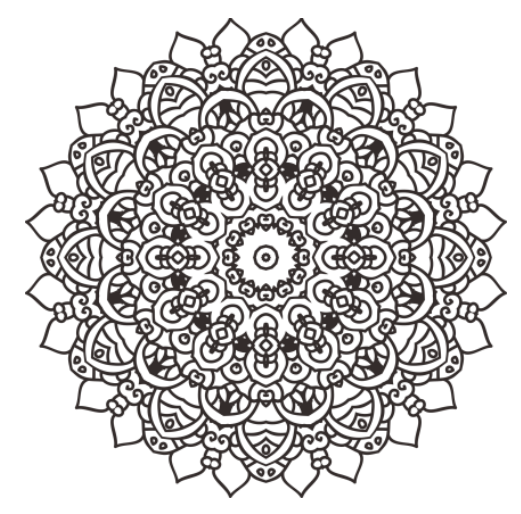

\title{
ISLAM NUSANTARA's Perspective on JUSTICE IN POLYGAMY
}

\author{
Beni Ahmad Saebani \\ Universitas Islam Negeri Sunan Gunung Djati Bandung \\ Email : benysyaebany@gmail.com
}

\begin{abstract}
A man is allowed to marry more than one woman with one important requirement, have an ability to act fairly. The sources of Islamic law, the Al-Quran and AsSunnah, do not explain in detail the procedures or techniques of fairness for polygamous husbands. However, in the Law No 1 of 1974 concerning Marriage there are articles governing poligamy, as in Article 4 and Article 5. Those provisions show that in the context of Islam Nusantara figh, polygamy is open to all men who want to marry more than one woman, but at once closed to a man who unable to the legislation requirements. Through literature studies with jurudic-normative approach, this study found that Indonesia has its own approach to ensure that a polygamous husband can act fairly toward his wives. The article 4 and 5 of Law No. 1 of 1974 on Marriage proofing the intention. Therefore, the position of legislation as a result of Islamic Law transformation into national law becomes a concrete form of Islam Nusantara's figh that has been applied in Muslim community life.
\end{abstract}

Key words: fairness, Polygami, fiqh of Islam Nusantara 


\begin{abstract}
Abstrak: Seorang suami boleh beristri lebih dari seorang dengan syarat memiliki kemampuan melaksanakan keadilan. Sumber hukum Islam, yakni Al-Quran dan AsSunnah tidak menjelaskan secara rinci tata cara atau teknis melaksanakan keadilan untuk suami yang poligami. Akan tetapi di dalam Undang-undang Nomor 1 Tahun 1974 tentang Perkawinan terdapat pasal-pasal yang mengatur prinsip keadilan secara yuridis dan teknis, sebagaimana pada Pasal 4 dan Pasal 5. Dengan ketentuan peraturan perundang-undangan tersebut dapat dipahami bahwa dalam konteks fiqh Islam Nusantara poligami terbuka untuk seluruh pria yang hendak menikahi lebih dari seorang isteri, akan tetapi sekaligus tertutup bagi pria yang bermaksud melakukan poligami apabila tidak terpenuhi persyaratan yang ditetapkan oleh peraturan perundangan-undangan yang berlaku. Melalui studi literatur dengan pendekatan yurudis-normatif, penelitian ini menemukan bahwa Indonesia memiliki pendekatan sendiri untuk memastikan bahwa suami yang poligami dapat bertindak adil terhadap istrinya. Pasal 4 dan 5 UU No. 1 tahun 1974 tentang Perkawinan membuktikan niat tersebut. Oleh karena itu, posisi legislasi sebagai hasil transformasi Hukum Islam menjadi hukum nasional menjadi bentuk konkret fiqh Islam Nusantara yang telah diterapkan dalam kehidupan masyarakat Muslim.
\end{abstract}

Kata Kunci: Keadilan, Poligami, Fiqh Islam Nusantara. 


\section{Introduction}

In Law Number 1 of 1974 Article 4 paragraph (1), a husband who wants to conduct polygyny must fulfill the following conditions: a. Approval of the wife/ wives; $b$. There is certainty that the husband is able to guarantee the life necessities of his wives and children; $c$. There is a guarantee that the husband will be fair to their wives and children. ${ }^{1}$

Article 5 paragraph 1 explanation states that the husband must ask permission from his wife, then the wife with any conditions, for example a wife who cannot give decendants has a prerogative right to give or not give permission to her husband who intends polygamy. However, with the understanding of Article 4 paragraph (2) (a) of theLaw, the position of an infertile/barren wife is in a dilemmatic position, trapped in adverse options of regulation enactment that alleged to be more beneficial for the husband.

In the Republic of Indonesia Government Regulation Number 9 of 1975 concerning the Implementation of Law Number 1 of 1974 concerning Marriage (GR No. 9/1975), Article 40 states that if a husband intends to have more than one wife, he must submit a written application to the Court. Article 41 stipulates that after the husband has filed his petition for polygamy, the Court shall examine any reason to allow a husband to remarry, one of which is if his wife can not give descendant, equipped by oral or written consent from the wife. In addition, a guarantee of the husband to support his wives and children, where the courts focuses examining the husband's income statement signed by the treasurer of his workplace, income tax certificate, or other acceptable letter by the Court.

In GR No. 9/1975article 41 letter (d) affirms that the husband should act fairly to all of his wives, therefore the Court makes asure that the husband will be fair to his wives and children in a form of agreement letter made specified for it.

Fairness that stated in Act No. 1/1974 and the GR No. 9/1975 is solely on material and financial fairness, not a single sentence expressing fairness from the feelings or minds of the polygamy wife side. A strict examination upon severe requirements for husbands who will do polygamy seems complicating the man to perform polygamy. These strict requirments will encourage the husband to find another way to fulfill his intention. For example, if the barren wife refuses to give permission for her husband to remarry, the husband can file a divorce to the Court and use infertile wife as the reason as regulated in GR No. 1/1975 article 19.

Is it possible that the wife "will not" give the permission? She is cornered by the stipulation as explained above, while the regulations do not give any benefit for the wife if the condition is reversed, where the barren party is the husband. Is there a choice for the wife? As a choice that is justified by laws and regulations.

\footnotetext{
${ }^{1}$ Marriage Law, (Yogjakarta : Library Widyatama, 2004), p. 9.
} 


\section{Theoretical Framework and Research Approach}

Marriage is a need for human nature whose legal position can changes based on certain conditions, from forbidden (haram), obligatory (wajib), disapproved (makruh), and recomme ded (sunnah). ${ }^{2}$ For someone who does not have external or inner abilities to be married, according to Sayyid Sabiq the law is haram. He is not allowed to marry because it will endanger marriage life. Marriage requires physical and mental readiness, so that in the context of the Law it is affirmed that marriage is an inner and outer bond. ${ }^{3}$

A marriage that conducted on the basis of readiness, both inwardly and outwardly; is used by the Law No. 1/1974 as barometer of a perfect bond between two persons in building their familiy. the words "inwardly and outwardly" mean that both bride and groom have sufficient age, and reach their adulthood. According to the Law, the ages are 16 year for women and 21 year for man as stipulated in article 7. The age is required to assure their readiness to think and act as an adult. In addition, both bride and groom havegood physical condition.

Men are obliged to protect and fulfill the needs of their family, especially in material aspects. ${ }^{4}$ Islamic law guides people to build family on the basis of mutual understanding and responsibility, especially the husband and wife are fully aware of their rights and obligations respectively. The Law No. 1/1974, affirms that the principle of marriage is a sacred contract between husband and wife with the aim to form an everlasting $6 \pi$ and happy family. An everlasting family means that the family will not ruined by divorce. While happy means sakinah, mawaddah warahmah, a family which filled with a sense of love and affection.

Marriage is another rulling of unity or engagement, as is the outwardly and inwardly bond. Not a single human being can resist a breakup. However, the bond can be strengthened by the maximum effort of husband and wife, so that the bond can only be broken by principal reasons. For example, if the household is maintained, it will bring greater adverse effects than its benefit. In other word, the divorce will be more beneficial than retaining the marriage. ${ }^{5}$

Polygamy is a husband's behavior justified by al-Qur'an and by the Law with certain requirements. The husband must be able to act fairly. Fairnessis very difficult to prove, because the one who can do fairly is only the Just (al-'Adlu). However, to reach this condition the Law regulates it very tightly. One of them is that for a husband who intends to polygamy must ask permission from his first wife, even the wife must state it before the panel of judges in the Religious Court. Polygamy is like a thorn that will hurt

2 Sayyid Sabiq, Fiqh Sunnah, Translation of Muhammad Tholib, volume 7, (Bandung : al-Ma'arif, , 2004) p. 22-24.

${ }^{3}$ Law Number 1 Year 1974 About Marriage, (Yogjakarta : Pustaka Widyatama, 2004) p.2.

${ }^{4}$ U. Abdurrahman, Tafsir Ahkam Volume II, (Bandung : Habibi Press, 2008) p. 22.

${ }^{5}$ Slamet Abidin, Fiqh Munakahat, (Bandung : Pustaka Setia, 2006) p. 17. 
wives, but regardless of the wife's feeling, polygamy remains justified by Islam and the Law with stipulated requirements.

The provisions on polygamy are not only contained in Law No. 1/1974, but also in the GR No. 9/1975 and the Compilation of Islamic Law. More fundamentally, everything is taken from the source of Islamic Law. Polygamy is part of men life. As guidances, the Prophet Muhammad SAW gave examples in polygamy. In Al-Qur'an, Surrah an-Nisa verse 3 it is stated that "and if you fear that you cannot act equitably towards orphans, then marry such women as seem good to you, two and three and four; but if you fear that you will not do justice (between them), then (marry) only one or what your right hands possess; this is more proper, that you may not deviate from the right course. ${ }^{\prime 6}$

In the context of Law No. 1/1974, polygamy must be based reasons that are appropriate and justified by law. One of the justified reason is if a wife cannot give offspring or a wife cannot fulfill her obligations as a wife due to severe illness or permanent physical disability..

With the existence of Law No. 1 of 1974 which complicates polygamy practices, have give understanding that women or wives are protected for being degraded by men, especially by her own husband. Therefore a husband who intends to polygamy must ask for approval from his wife, and the intended permission must be stated in front of the panel of judges in the Court. ${ }^{7}$

Although polygamy is hard to do because of the requirement, it does not discourage men to practice polygamy. With the existence of Law Nol.1/1974 and GR No. 9/1975, it shows that polygamy will always exist, and men get special place if they have the will. As for women, as wives, to get a place that is respected by Islamic law and Law No. 1/1974, that her husband is required to act fairly; even more, that the husband's marriage can be declared as illegal his former wife did not give any formal consent. Whatever the form of applicable law, it is substantially regularizing, binding, sanctioning, and forcing humanity as the object and subject of law to behave by obeying the law, as well as executor of the existing law. Thus the law normatively has a special feature, namely to protect and provide balance in keeping public interest. In accordance with its objectives, namely to achieve orderliness for the sake of justice, the rule of law will develop in line with the development of human life.

Marriage is part of civil law. From the existence of marriage there arises family, joint property, children, guardianship, inheritance, and so on. In Islamic teachings, marriage it is not simply a relationship that occurs between men and women, but it relates to the nature of human and the Sunnah of the Prophet which refers to one's intention to get married.

This research was carried out with normative juridical method, by reviewing the laws and regulations that apply in Indonesia which related to marriage and polygamy.

\footnotetext{
${ }^{6}$ Soenarjo et al., Al-Quran and its Translation, (Jakarta : Ministry of Religious Affairs, 2005) p. 115.

${ }^{7}$ Rahmat Hakim, Islamic Marriage Law, (Bandung : Pustaka Setia, 2007) p. 114.
} 
Information tracking techniques apply the library research method with primary legal materials Law Number 1 of 1974 concerning Marriage, Government Regulation Number 9 of 1975 regarding the Implementation of Law Number $1 / 1974$ and Compilation of Islamic Law. Whereas the secondary legal materials are in form of verses from al-Quran and Hadith which explain polygamy, and Indonesian scholars opinions through their writing works. Those legal materials were analyzed with content analysis approach and then concluded according to the research objectives.

\section{Polygamy due to wife is unable to fulfill her obligations}

According to Law No. 1/1974 as contained in articles 3-5, polygamy can be interpreted as marriage of a husband with more than one woman. Polygamy can not be denied, it is sociologically impossible to avoid, and is juridically protected. ${ }^{8}$ Polygamy will practically continue to live among the mature and among the civilized majority of mankind. If polygamy is prohibited, infidelity and adultery will be pervasive.

According to Law Number 1 Year 1974 polygamy is a marriage that refers to several terms and reasons. The requirement is that the husband gets the approval of his wife and is justified through trial in the Court, while the reasons are if the current wife is barren, disabled or has severe illness that made her unable to carry out her obligations as a wife. Those reasons can be used by the husband if he intends to do polygamy.

In relation to the permitable of polygamy as affirmed by Law No. 1 of 1974, automatically force the husband to apply justice principle in his household management. According to Law No. 1 of 1974 to uphold justice and fairness, a husband who intends to do polygamy must be able to guarantee that justice will be carried out properly and correctly.

Al-Hamdani said that, "Justice in polygamy means proportional in attitude and action, materially and spiritually, lahiriyah and bathiniyah. The wifes provides a meaningful place for polygamous husband, while the husband outpoures love for all of his wives rationally and equally." 9

The justice intended by Law No. $1 / 1974$, as stipulated in Article 5 is fairness in material or outwardly, which can be measuredmathematically. It differ with justice for inwardly (bathiniyyah) which difficult to measure because it involves feeling or heart, known only the husband and the polygamous wifes. In this connection, material justice is easy to reckon with, but inner justice is difficult to measure. ${ }^{10}$

In addition to Law No. 1/1974, GR No. 9/1975 and Compilation of Islamic Law as a material law for Moslem, for Civil Servants, there is another law regulating marriage and divorce procedures, including polygamy, which is Government Regulation Number 10 of

\footnotetext{
${ }^{8}$ Sayyid Qutub, Islamic Answers to Western Civilization, (Bandung: Pustaka, 2007) p.45

${ }^{9}$ Al-Hamdani, Risalah Nikah, (Jakarta : Pustaka Amani, 2007) p. 79

${ }^{10}$ Rahmat Hakim, Marriage Law ... p. 114
} 
1983 concerning Marriage and Divorce permits for Civil Servants (GR No. 10/1983). As a material law for Muslims, there is a provision in the Compilation of Islamic Law (KHI).

Generally, those regulations are based on the principle of monogamy, one husband for one wife. In certain cases or reasons, a husband is permitted to have more than one wife. This matter or reason is reflected in a series of heavy requirements. A decision whether a husband can marry more than one woman is determined by the Religious Courts based on the fulfillment of the requirements.

The severity of the requirements implied that the practice of polygamy in the Religious Courts embraced the rule of closing the open door, meaning that polygamy is limited if it was not necessary and only open in certain cases or circumstances.

Juridical reasons for polygamy are opened as previously explained, according to Law No. 1/1974 article 4, which consists of 2 paragraphs reads as follows: (1) In the event that a husband will marry more than one as mentioned in Article 3 paragraph (2) of this Law, he shall apply to the local court of his residence; 2 ) The court referred to in paragraph (1) of this Article only gives permission to a husband who will have more than one wife if: $a$. The wife cannot fulfill her obligations as a wife; $b$. The wife has disability or an incurable disease; $c$. Wife cannot give birth to children.

The explanation of paragraph 2 states that a husband who intends to do polygamy must provides a substantial reason which is truly proven, but there is no further explanantion on "wife who cannot carry out her obligations as a wife". For this, it relates to Article 30 of Law No. 1/1974, that wife's obligation is manage and uphold her household as a foundation of society structure. Further, in the same article, it said that it is not only the obligation of the wife but also the obligation of the husband. It is not clearly explained in the article how a wife cannot uphold the household. However but there are several indicators that can be use, namely: (1) disobedient; (2) improvident; (3) unwilling to live with her husband in a residence provided by her husband; and (4) has physical or mental illness that is difficult to cure.

If the indicator is the four things above, why should a husband choose polygamy? Whereas in Article 39 Paragraph 2 of Law No. 1/1974 it is stated that to have divorce there must be enough reasons, that the couple will not be able to live in harmony as husband and wife. Especially if consider the GR No. 9/1975 Article 19 that divorce can occur for the following reasons: (a) One of the parties commits adultery or becomes a drunkard, drug addict, gambler, etc. that is difficult to cure; (b) One of the parties leaves the other for 2 (two) consecutive years without permission from the other party and any legitimate reason, or any other matter beyond his or her ability; (c) One of the parties gets a 5 (five) year prison sentence or a heavier sentence after the marriage takes place; (d) One of the parties commits severe cruelty or persecution that endangers the other party; (e) One of the parties has disability or illness that cause inability to carry out obligations as a husband or wife; $(f)$ There is continuing disputes and quarrels between the couple and there is no hope to retain the household. 
Reffering to those reasons for divorce, they can be categorized as "non-reinstatement condition". One of the reasons a husband apply for polygamy is if the wife is unable to carry out her obligations as a wife, while one of the wife's obligations is to uphold the household as the basic foundation of the society. If the wife cannot do this obligation, unquestionably the husband is "not absolutely" requisite his wife's consent to do polygamy, since a wife who does not carry out her obligations can be categorized as a wife who may be divorced by her husband, in other words a wife who is nusyuz (disobedient to her husband), unless the couple make peace.

In the GR No. 9/1975, Article 40 explains that if a husband intends to polygamy, he shall submit a written application to the Court. This article is an affirmation to implement Law No. 1/1974 Article 4. Furthermore, in article 41 of the GR stipulates that the Court examines the following matters:

1. The availability of reasons that allow a husband to remarry, which are: a. that the wife cannot carry out her obligations as a wife; $b$. that a wife has disability or an incurable illness; $c$. that the wife cannot give birth to any children.

2. The availability of wife's concent, whether oral or written. If the consent is, then it consent shall be spoken before the court;

3. The availability of an agreement upon husband's ability to guarantee his wives and childerns life necessities, by showing:

i. Reference letter on husband's income signed by the treasurer of his workplace, or

ii. Reference letter of Income tax; or

iii. Other statements acceptable by the Court.

4. The availability of assurance that the husband will be fair to his wives and children, in form of statement or promise specifically made for it.

The polygamy application to the Court must be equipped with the following requirements: (1) Letter of application for polygamy; (2) Reasons for polygamy; (3) Letter of approval from the wife; (4) Certificate of income from the workplace signed by the treasurer; (5) Certificate of income tax; and (6) Letter of agreement on a paper seal regarding the guarantee to act fairly and justice to all of his wives and children.

The Court's examination shall be verified by summoning the wife who gave the consent letter, as affirmed in Article 42 Paragraph (1) that in examination process upon Articles 40 and 41 requirements, the Court shall call and perceive the wife. The Judicial Review shall be conducted by the Judge not later than 30 (thirty) days after the receiving of the application letter and its attachments. If the Court comes to conclusion that the reason is sufficient for the applicant to have more than one wife, the Court shall give its rulling by giving permission to the applicant for having more than one wife (Article 43).

Based on the above stated articles, it may be concluded that the juridical justification for a man to practice polygamy is because the submitted application has been declared appropriate by the Judges panel in the Court, where the applicant meets 
all the terms and reasons requiredin the Law No. 1/1974 and GR No. 9/1975. On the other hand, if the applicant failed to fulfill the required conditions and reasons, the application will automatically be rejected. Thus, if the polygamy is still carried out without court's permission, the marriage will be considered as against the law and illegal.

The reasons for for divorce according to Article 4 Paragraph 2 letter (a) have substantial differences with GR No. 9/1975 Article 19 letter (e), namely: 1. Article 4 Paragraph 2 letter (a) of the Act. No. 1/1974 is only for filing polygamy because the wife cannot carry out her obligations as a wife, while PP. 9/1975 Article 19 letter (e) states that a husband or wife who cannot carry out their obligations due to disability or incurable illness; 2 . Although the cause of the wife's failure to fulfill her obligations is not stated by Article 4 paragraph 2 letter (a), the word "cannot" can be understood as "unintention ally", due to certain reasons, for which most likely disability or incurable disease; 3 . For this reason, the husband has two choices, namely polygamy or divorce his wife, while for the wife has only one choice, namely filing a divorce.

With the above juridical considerations, the meaning of "the wife cannot carry out her obligations as a wife" is as follows: (1) A wife who does not have the power and effort to serve all the needs of her husband, both physically and inwardly. The wife in question has a physical disability or suffers from a severe illness.; (2) A wife who have had a hysterectomy, therefore unable to give any childrenbirth; (3) A wife who is too busy with her career, so that her time is more for her own benefit than serving her husband; (4) A wife who deliberately leaves her obligations as a wife; (5) A wife who is terrible in managing her household affairs.

The meaning of "a wife who can not fulfill her obligation as a wife" is related to the rights and obligations of husband and wife as mentioned in Article 30-34, Law No. $1 / 1974$.

In Article 31 husband and wife rights and obligations are: (1) The right and position of a wife is equal to the rights and position of the husband in the life of the household and the common life in society; (2) Each party has the right to take legal actions; (3) Husband is the head of the family and wife is the housewife.

Article 32 states that: (1) A husband and wife must have a permanent residence; and (2) The residence house as stated in paragraph (1) of this Article shall be determined together by the couple.

Article 33 stipulates: "Husband and wife shall love, honor, be faithful and supports each other both inwardly and outwardly."

Article 34 regulates that: (1) A husband is obliged to protect his wife and provide everything that needed for the household live based on his ability; (2) The wife is obliged to regulate household affairs as well as possible; and (3) If a wife or husband neglects their obligations, one of them may file a lawsuit to the Court. 
In the Compilation of Islamic Law Chapter XII, the rights and obligations of Husband and Wife are divided into six parts.

Part One, General Provisions, is the article 77 which contains the same material as Article 30-34 of Law Number 1/1974.

Part Two, the Status of Husbands and Wives, Article 78 states: (1) The husband is the head of the family, and the wife is the housewife; (2) The right and position of a wife is equal to the rights and position of the husband in the life of the household and the common life in society; (3) Each party has the right to take legal actions.

Part Three, The Obligations of Husband in Article 80 stated that: (1) Husbands are mentors to their wives and households, but important matters concerning household are decided by both husband and wife; (2) Husband is obliged to protect his wife and provide everything for the household life according to his ability; (3) Husbands are obliged to provide religious education to their wives and provide opportunities to learn knowledge that is useful and beneficial to religion and nation.

In accordance with his income, the husband bears: (1) Livelihood, kiswah (clothes) and residence for the wife; (2) Household expenses, maintenance and medical expenses for wives and children; (3) The cost of education for children; (4) The obligation of the husband to his wife as referred to in paragraph (4) letters a and $b$ above shall take effect after a perfect tahkim there is a perfect decree from his wife; (5) The wife can free her husband from his obligations to her as referred to paragraph (4) letters a and $b_{;}$(6) The husband's obligation as referred to paragraph (5) shall be void if his wife is nusyuz (disobedient).

Part Four, Residence as stipulated in Article 81 are: (1) Husbands must provide a place of residence for his wife and children or ex-wife who is still in the iddah (waiting period after separation); (2) A residence is a decent place to live for a wife during marriage or in iddah from divorced or bereaved ${ }_{i}^{11}$ (3) A residence is provided to protect his wife and children from interference from others, so they feel safe and secure. The residence also serves as a place to store wealth, as a place to organize household appliances; (4) The husband must equip the residence according to his ability and adapted to the condition of the environment in which he lives, both in the form of household appliances and other supporting facilities.

The fifth part, the obligation of a husband who has more than one wife, Article 82 which reads: (1) A husband who has more than one wife is obliged to give each wife a place of residence and living expenses equally according to the size of the number of families borne by each wife, unless there is a marriage agreement; $(2)$ In the event that the wife is willing and sincere, the husband can place his wives in one residence.

${ }^{11}$ iddah is a waiting period for women after divorce with her husband due to ordinary divorce or because her husband died. 
Part Six, the Obligation of Wives, in Article 83 which reads: (1) The primary obligation of a wife is to be devoted to her husband, inwardly and outwardly within the limits justified by Islamic law; (2) Wife organizes and regulates the daily needs of the household daily life as well as possible.

Article 84 states: (1) Wife can be considered as nusyuz if she does not want to carry out obligations, as meant in Article 83 paragraph (1), except for a valid reason; (2) As long as the wife is disobedient (nusyuz), the husband's obligation as in article 80 paragraph (4) letters a and b does not apply except for matters of child's interest; (3) The obligation will be reinstated if the wife returns to obey her husband. of the husband as referred to in paragraph (2) above applies again after his wife is not ungodly; and (4) A ruling of the wife's nusyuz act must be based on valid evidences.

The rights and obligations of husband and wife according to Law No. 1/1974, GR No. 9/1975 and Compilation of Islamic Law are very complete. The right of the wife is the obligation of the husband. On the other hand, the right of the husband is the obligation of the wife. The rights of the wife to her husband include: (1) Material rights, namely dowry (mahar) and livelihood; (2) Spiritual rights, such as act fairly if her husband is polygamous and must not harm his wife.

A wife is obliged to do the following: (1) Serving the needs of her husband physically and inwardly; (2) Preserving the good name and honor of her husband and possessions; (3) Serve piously to the religious teachings and leadership of her husband as long as they are not conflicting to Islamic law.

With the explanation above, the meaning of "the wife cannot carry out her obligations as a wife" is the opposite of all obligations that must be carried out as a wife, intentionally or unintentionally.

In Law No./1974 concerning Marriage Article 4 and 5 there is not a single verse which explains a husband who cannot carry out the obligations, even though logically this can happen to the husband. The article has determined that the wife is the party who commit it, therefore the husband can obtain permission to polygamy from the Court, while a woman is prohibited to do polyandry.

Textually. Law No. 1/1974 provides a basic understanding of a husband position as the head of a family, since one of marriage goals is the journey of a husband leadership journey that is followed by his wife. This household leadership becomes a religious and law demand, because without leadership there will be no relation between the leader and their dependent. Then, if a wife can not fulfill her duties as a wife that means she is incapable to hold a position as a wife. In this case, the husband will need alternative or solution, thus his position is firm as the head of the family and there is a clear tasks division between him and his wife who is legally married according to religious teachings and applicable laws.

When a wife can not perform her duties, as explained in Article 4 Paragraph 2 letter (a), the husband is allowed to submit polygamy permission to the Court. In 
contrary, the wife may refuse her husband intention as stipulated in the Act. This was questionable, her inability to carry out her obligation as a wife may put her into dillematic position since her condition may be used as a reason for the husband to divorce her. The choices are very clear, whether she will be divorced or be polygamous.

According to Article 5 Paragraph 1 letter (b), the polygamy application must be completed with an assurance that the husband is able to provide live necessities of his wives and children. The former wife may declare before the court about her husband's livelihood, his monthly or annual income then rationalized with the household needs for primary necessities such as food, shelter and clothing. If the income is below the requirements or the deficiency is very significant, the Court will consider rejecting the application. From the inadequate income, it can be concluded that the husband cannot afford the life necessities of his wives and children, which will be ended to the injustice or further a despotic act toward his wives and children.

The provisions contained in the letters (b) on husband's ability to guarantee his family's expenses gives an understanding that polygamy can be done not only due to impious wife. The phrase "wives and children" in the article means that the polygamy applicant has at least a wife and a child or more. Thus, if his reason is "wife can not fulfill its obligation", it must be interpreted that the condition has been happen from the beginning of the marriage or during the marriage due to particular circumstances, such as birth labor or illness. In contrast to the sentence "the wife cannot carry out her obligations", the sentence "if any, even though it is not actually available" in the same article can be understood that the wife has fulfilled her obligations, but due to certain causes that are unintentional and unintended, such as illness with physical-threatening diseases, then the content of Article 4 Paragraph 2 letter (a) is relevant to the reasons in letter (b) ie "the wife is disabled or suffer from illness that made her unable to perform her obligation as wife."

From those understanding, the reason that a wife can not fulfill her obligations can be interpreted as: (1) the wife refuses to perform her duties and functions as a housewife which made the husband submits the polygamy application to the Court; and (2) the wife is unable to provide biological services due to sickness or disabilities; (3) The wife who is nusyuz (disobedient).

The interpretation of Article 5 Paragraph 1 letter (a) of Law No. 1/1974 above provides an opportunity for the wife to take actions that are justified by the Law, namely not giving her husband's consent for polygamy because of insufficient income to meet the needs of his household life and believe that the husband will not act fairly. For this reason the letter $\mathrm{c}$ of the same article requires a firm statement from the husband, an assurance that he will act fairly to all of his wives and children.

If the husband imposed his will on polygamy, while the wife did not give her consent through the Court, and the Court did not grant the polygamy permission, a justified act that can be took by the wife is suing her husband for divorce. 
This can be done by a wife if there is no reason against her; where she able to bring a child or more and she dutifully fulfilled all of her obligation as wife until a certain circumstance restained her to do so. Different conditions can be applied if the wife was medically declared as infertile and barren, so it can be concluded that "the wife cannot carry out her obligations as a wife." reasonable enough for the husband to file polygamy.

Even so, a wife who cannot carry out her obligations as a wife since her marriage does not mean that she is prohibited to file a divorce. It is acceptable for a woman who chooses divorce rathen than being polygamous.

From several explanations to the Article 4 and 5 of Law Number 1/1974, it can be concluded that the wife may react to the husband application in several actions, which are: (1) The wife does not give consent to her husband for polygamy orally or in writing before the Panel of Judges in the Court; (2) The wife declares at the same time explains the husband's livelihood, rationalized the income with their household's needs in clothing, food, housing, whether it issufficient to guarantee the life necessities of life of his family; (3) The wife file a divorce due to her rejection upon the husband polygamous; (4) The wife asks the husband to apply talaq (divorce affected by husband) to the court so the husband did not practice polygamy, but as a widower remarry another woman; nad (5) The wife gives permission to her husband.

\section{Polygamy in the Context of Islam Nusantara Law}

In the context of Islam Nusantara, , the Law No. 1/1974 is not just a transformation of Islamic law to national law in Indonesia, but already became taqnin and tathbiq of Islamic law in the life of the state, especially for Muslims. One of the fundamental reasons is the absence of Al-Quran and Sunnah verses that explain in detail the procedures to implement polygamy, the stages, and the mechanism of the operational mechanism of justice in polygamy.

Al-Quran the letter An-Nisa verse 3 Allah swt. states that a man may marry women two, three and four, and if they are unable to do justice, then just marry a woman. What the meaning of justice in this verse is not specified in technical terms and procedures. However, in Law No. 1/, Article 4, paragraphs 1 and 2, are presented for reasons not available in the Qur'anic and Sunnah texts, for example "a wife can not fulfill her obligations as a wife."

Similarly, the GR No. 9/1975 Article 41 mentions matters relating to the implementation of Law No. 1/1974 relating directly to Article 4, as already explained on the previous part that for both the husband and wife's interests, the Court examines every evidence that proofs the husband has ability to provide his wives and children sufficiently, by taking into account a written guarantee that the husband will act fairly to all of his wives and children.

Those stipulations show the characteristics and model of Islam Nusantara which made into national law, therefore it becomes a distinctive model of Islamic law. In 
addition to prioritizing the benefit (maslahah) approach to achieve a sakinah mawaddah warahmah familiy, as well as the appropriate method to raise and preserve the status and dignity of women who have been marginalized socially, culturally, and even in the context of religious comprehension in Indonesia.

\section{Conclusion}

Upon the research results, some points can be concluded as follows: (1) Polygamy is one of the blessings of Allah Almighty for men as stipulated in the al-Qur'an and exemplified by the Prophet Muhammad SAW on one condition that the husband implements it on the principle of justice; (2) In the context of Islam Nusantara, the principle is interpreted through laws and regulations, administratively and socioeconomically and gender equality; (3) The applied approach is the benefit (maslahah) approach and rejecting harm in building a family according to the objectives of Islamic law.

\section{BIBLIOGRAPHY}

Abdoel Djamal, Introduction to Law in Indonesia. Jakarta : Raja Grafindo Persada, 2008. Marriage in Indonesia. Jakarta : Raja Grafindo Persada, 2009.

A. Hamdani H.S.A, Marriage Issue of Islamic Marriage Law. Jakarta : Library Amani, 2007.

A. Mukti Arto, The Practice of Civil Cases in the Religious Courts. Yogjakarta : Student Library, 2007.

Aminudin, Fiqh Munakahat. Bandung : Pustaka Setia, 2007.

Anonimous, Religious Courts Act (Law No. 7 of 1989) Supplemented by Decree of the Minister of Religious Affairs No. 73/1993 on the determination of the State Court Class. Jakarta : Sinar Grafika, 1996. Marriage Law in Indonesia. Surabaya : Arkola, 2007. Republic of Indonesia Government Regulation Number 9 of 1975 Equipped with Compilation of Islamic Law. Surabaya : Arkola, 2004. , Law Number 1 of 1974 and its Explanation Equipped with PP. No. 9/1975 and PP. No. 10/1983 concerning Marriage and Divorce Permits for Civil Servants. Yogjakarta : Reader Widyatama. 2004. Association of Laws and Regulations, Marriage Law in Full Edition. Bandung : Focus Media, 2004. , Compilation of Islamic Law. Bandung : Focus Media, 2004.

Bakri A. Rahman, Marriage Law According to Islam, Marriage and Civil Law Law, Jakarta: Hidakarya Agung, 2007.

Rahmat Hakim, Islamic Marriage Law, Bandung : Pustaka Setia, 2006. 
Beni Ahmad Saebani, Islamic Nusantara's Perspective on Justice In Polygamy...| 15

Sayyid Sabiq, Fiqh Sunnah, terjemah Muhammad Tholib, Volume 7, Bandung: Al-Ma'arif, 2004.

Slamet Abidin, Fiqh Munakahat, Bandung : Pustaka Setia, 2006.

Soenarjo et al, Al-Qur'an and Translation. Jakarta : Depag R.I., , 2007.

Soerjono Soekanto, Introduction to Legal Research, Jakarta : UI-Press, 2005.

U. Abdurrahman, Tafsir Ahkam Volume II, Bandung : Habibi Press/ 2008. 
16 | Asy-Syari'ah Vol. 21 No. 1, Juli 2019 
Asy-Syari'ah (P-ISSN : 2086-9029 E-ISSN: 2654-5675) is a periodical scientific journal that publishes various results of studies and research, literature review, and other scientific works whose scope covers the field of Islamic law/sharia, law and society in monodisciplinary, interdisciplinary, and multidisciplinary manners. The journal aims to expand and create innovative concepts, theories, paradigms, perspectives and methodologies in the above said scope. The Journal is published twice a year (june and december) by Faculty of Shariah and Law, Sunan Gunung Djati State Islamic University Bandung in collaboration with Asosiasi Sarjana Syariah Indonesia (ASSYI).

\section{EDITORIAL OFFICE:}

Fakultas Syariah dan Hukum UIN Sunan Gunung Djati Bandung Jl. Raya A.H. Nasution No. 105 Cibiru Kota Bandung, 40614

Tlp/Fax: +022-7802278 Faks. 022-7802278

Website http://journal.uinsgd.ac.id/index.php/asy-syariah/index

E-mail: Jurnalasy-syariah@uinsgd.ac.id 